Научная статья

УДК 355.231.1:63

DOI: $10.18101 / 2307-3330-2021-3-92-96$

\title{
ФОРМИРОВАНИЕ ОБЩЕКУЛЬТУРНЫХ КОМПЕТЕНЦИЙ У СТАРШЕКЛАССНИКОВ КАДЕТСКОЙ ШКОЛЫ-ИНТЕРНАТА НА ЗАНЯТИЯХ ПО ИСТОРИИ
}

\author{
() Шкильнюк Александра Сергеевна \\ магистрант, \\ Бурятский государственный университет имени Доржи Банзарова \\ Россия, 670000, г. Улан-Удэ, ул. Пушкина, 25 \\ alexsandra.shkilniuk@gmail.com
}

\begin{abstract}
Аннотация. Данная статья посвящена основной задаче российского образования - обеспечение государства высококультурными личностями, способными не только владеть теоретическими знаниями, но и применять эти знания в различной деятельности. В статье речь идет об особенностях формирования общекультурных компетенций на занятиях по истории у учащихся старших классов с точки зрения социально-культурных аспектов. Автор дает определение компетенции в целом и социально-культурной компетенции в частности. В данной статье рассматриваются европейская и отечественные классификации ключевых компетенций. Также обозначены направления формирования общекультурных компетенций на уроках истории, вместе с тем предложены возможные варианты работы с учащимися старших классов на урочных и внеурочных занятиях по дисциплине «История», направленные на формирование общекультурных компетенций.
\end{abstract}

Ключевые слова: общекультурные компетенции, старшеклассники, урок истории, социально-культурный аспект, межпредметные связи, мероприятия.

\section{Для цитирования}

Шкильнюк А. С. Формирование общекультурных компетенций у старшеклассников кадетской школы-интерната на занятиях по истории // Вестник Бурятского государственного университета. Образование. Личность. Общество. 2021. № 3. С. 92-96.

В настоящее время российское общество испытывает духовно-нравственные затруднения. Актуальность проблемы «высококультурного человека» в современном обществе обусловлена качественными, всесторонними изменениями в политической, экономической и других сферах жизни многих стран мира.

Сейчас же, когда общество стремительно преображается и трансформируется, выходит на принципиально новую, другую ступень своего развития, государство приняло во внимание, что необходимо представить обновленный социальный заказ на качественно иную личность. Государственный заказ направлен на формирование такой компетенции, как общекультурная. Вследствие этого вопрос культуры значим, так как от уровня сформированности культуры граждан многое зависит, в частности, экономика, политика, престиж страны, также велико ее влияние на национальную безопасность и конкурентоспособность страны. Этим обусловлена актуальность темы статьи. В силу того, что формирование различных компетенций, прямо требуемых положениями ФГОС ООО, должно иметь место на протяжении всего периода школьного обра- 
A. С. Шкильнюк. Формирование общекультурных компетенций у старшеклассников кадетской школы-интерната на занятиях по истории

зования, представляется целесообразным проанализировать, каким образом могут быть сформированы общекультурные компетенции у учащихся старших классов на занятиях по истории с точки зрения социально-культурных аспектов их формирования. Необходимо отметить тот факт, что уроки истории в старших классах обладают значительным потенциалом с точки зрения формирования общекультурных компетенций, поскольку на современных уроках истории имеет место реализация многочисленных межпредметных связей, например, между историей и такими дисциплинами старшего этапа школьного обучения, как литература, иностранный язык, география, концепции современного естествознания и т. д.

В первую очередь необходимо дать определение компетенции в целом и общекультурной компетенции в частности. Отметим, что к настоящему моменту единое общепринятое определение компетенции в педагогической литературе нами не было обнаружено. Однако, исходя из анализа наличествующих по заданной теме первоисточников следует вывод, что все определения могут быть объединены исходя из осмысления компетенции в качестве совокупности взаимосвязанных качеств личности, которые напрямую воздействуют на эффективность деятельности индивида.

Одновременно с этим следует обозначить, что вопрос выделения ключевых компетенций по-прежнему остается открытым. Сложность рассмотрения понятия «ключевые компетенции» обусловливается множеством названий, используемых различными авторами в разных источниках. В частности, такие компетенции называются ключевыми, универсальными, базовыми, систематичными, транспредметными компетенциями и пр.

Классификации ключевых компетенций разными авторами также различаются. Так, в 1996 г. Ж. Делором были выделены следующие глобальные компетенции:

- научиться делать;

- научиться познавать;

- научиться жить;

- научиться жить вместе (доклад «Образование: сокрытое сокровище») [2, с. 3].

Отечественные педагоги также выделяли ключевые компетенции. И. А. Зимняя создала классификацию, в основе которой находится категория деятельности [4, с. 41]. Она выделяет такие группы компетенций:

- напрямую относящиеся к самому индивиду как личности, субъекту всевозможного общения;

- относящиеся к происходящему между индивидом и социальной средой социальному взаимодействию;

- относящиеся к осуществляемой индивидом деятельности [4, с. 42].

А. В. Хуторской предложил классифицировать ключевые компетенции посредством подразделения их на следующие группы:

- общекультурные;

- ценностно-смысловые;

- информационные;

- учебно-познавательные;

- социально-трудовые;

- коммуникативные; 
- компетенции личностного самосовершенствования [9, с. 62].

Далее разберем общекультурные компетенции и к каким способам можно прибегнуть, чтобы развить данные компетенции. Общекультурная компетенция личности есть сумма навыков, знаний и элементов культурного опыта, которыми владеет личность. Общая культура дает человеку шанс свободно ориентироваться в культурном и социальном окружении, а также оперировать его компонентами.

В соответствии с ФГОС ООО на уроках истории должны быть сформированы общекультурные компетенции, которые представляют собой конкретные проблемы, в которых учащийся должен грамотно ориентироваться, знать теоретические аспекты и уметь применять эти знания в практической деятельности. Здесь имеются в виду специфика культуры, культурологические основы общественных, социальных и семейных явлений, ценностей, традиции, влияние науки и религиозных верований на мир, их значение для жизни человека, а также компетенции в культурно-досуговой и бытовой сфере.

Во ФГОС среднего общего образования перечислены личностные результаты освоения основной образовательной программы, которые кратко можно свести к таким ориентациям, как самоопределение, т. е. сформировать российскую гражданскую идентичность, патриотизм, мировоззрение, толерантное сознание и поведение и др. Смыслообразование - сформированность осознанного выбора будущей профессии, готовность и способность к самообразованию, основы саморазвития и самовоспитания. Ценностная и морально этическая ориентация, направленная на формирование нравственного сознания, чувств и поведения, ценностей здорового и безопасного образа жизни, ответственного отношения к созданию семьи и др.

В процессе формирования общекультурных компетенций на уроках истории в старших классах необходимо учитывать также определенные психологические и педагогические аспекты их формирования, причем их можно охарактеризовать следующим образом:

1. Педагогические аспекты: использование разнообразных форм, средств, приемов и методов обучения, причем в качестве наиболее эффективного педагогического приема можно назвать творческие работы, а также иные приемы, о которых будет сказано далее.

2. Психологические аспекты, основными из которых можно назвать следующие: поддержание интереса учащихся к уроку истории; формирование мотивации работы не только на уроке, но и самостоятельно, особенно в ходе исследовательской работы; создание максимально комфортной среды на уроках истории.

Предусматривается несколько способов, используемых для формирования рассматриваемых компетенций на занятиях по истории, включающих урочную и внеурочную деятельность. Указанное обусловливается формированием благодаря воспитательной работе развивающей среды, способствованием духовному обогащению и эмоциональному насыщению жизни и деятельности детей и подростков.

Представляется возможным выделить ряд направлений в работе, заключающейся в формировании у обучающихся общекультурных компетенций, на занятиях истории. Это, в частности:

- интерактивные технологии, которые позволяют организовать процесс приобретения нового опыта и обмен имеющимися, максимально использовать личностный 
опыт каждого участника. Это совместная деятельность, моделирование, ролевые и деловые игры, проекты. Например, сюжетно-ролевая игра «Вече», этапная игра «Краеведческий калейдоскоп: почетные граждане города Стерлитамак», круглый стол «Глобальные проблемы человечества» и др. [10]

- исследовательские проекты различной тематики. Например, изучение истории родного края. Здесь дети смогут на основе информации, найденной в архивах, музеях и других источниках, восполнить дефицит знаний о своей малой родине. В качестве примера можно привести следующие проекты: «Выдающиеся земляки», «Памятники нашего города». Проекты по военной теме, где необходим поиск материалов о своих близких - участниках войны, памятных датах военной истории [6, с. 41]. Также исследования, касающиеся семьи: «Генеалогическое древо», «Происхождение фамилии».

- организация сюжетных выступлений об актуальных событиях современности (например, «Информационные пятиминутки», «Острый репортаж»);

- мероприятия, знакомящие детей с истории нашей страны (например, акция «Бессмертный полк», «Георгиевская ленточка», «Герои России», «Города-герои», «Диктант победы», «Письмо победы», «Шаги к победе» и другие) [5].

Особое внимание при формировании общекультурной компетенции следует обратить на учебную дисциплину «История», в рамках которой посредством исторической памяти, культуры и традиций народа происходит развитие духовной целостности и мировоззрения индивида.

В настоящее время современное поколение особенно нуждается в идеале. На примере деятельности, осуществляемой выдающимися историческими личностями, такими как Дмитрий Донской, Александр Невский, Сергий Радонежский, демонстрируется гражданская ответственность за судьбу своего народа и страны, а также истинный патриотизм.

Учитель истории в процессе преподавания своего предмета может способствовать формированию у обучающихся гордости за собственную страну, приводя конкретные примеры победы страны не только в военной деятельности, но и других областях.

Подводя итог, следует отметить, что воспитание, просвещение и успешное формирование общекультурных компетенций у молодежи происходит в рамках учебного курса по истории, в тесной взаимосвязи с мероприятиями духовно-нравственного, патриотического направления. Общекультурные компетенции развиваются самой личностью в ходе творческой деятельности, а основная же задача педагога по истории заключается в помощи учащимся и создании благоприятных условий для их дальнейшего становления.

\section{Лuтература}

1. Боровик М. Г. Общекультурная компетентность школьников как результат гуманитарного образования учащихся: поиски, проблемы, решения // Совершенствование школьного образования и проблемы преподавания гуманитарных предметов. Санкт-Петербург: Питер, 2000. С. 12-21. Текст: непосредственный.

2. Делор Ж. Образование: сокрытое сокровище. Москва: Изд-во ЮНЕСКО, 1996. 37 с. Текст: непосредственный.

3. Дериглазова Н. Г. Формирование общекультурной компетентности обучающихся // Первое сентября. URL: https://urok.1sept.ru/articles/510859 (дата обращения: 10.04.2021). Текст: электронный. 
4. Зимняя И. А. Ключевые компетенции - новая парадигма результата образования // Высшее образование сегодня. 2003. № 5. С. 34 42. Текст: непосредственный.

5. Киселева Е. А. Формирование общекультурных компетенций на уроках истории. URL: http://www.rusnauka.com/pdf/247255.pdf (дата обращения: 15.03.2021). Текст: электронный.

6. Княжева В. В. Формирование общих компетенций через нетрадиционные формы проведения внеклассных мероприятий // Образование и воспитание. 2015. № 2. С. 40-43. Текст: непосредственный.

7. Конасова Н. Ю. Общекультурная компетентность как показатель образованности учащихся школы : пособие для самообразования. Санкт-Петербург: Лань, 2000. 27 с. Текст: непосредственный.

8. Сибгатуллин А. Ю. Понятие и сущность общекультурной компетентности личности // Проблемы современного педагогического образования. 2019. № 63-3. URL: https://cyberleninka.ru/article/n/ponyatie-i-suschnost-obschekulturnoy-kompetentnosti-lichnosti (дата обращения: 12.04.2021). Текст: электронный.

9. Хуторской А. В. Ключевые компетенции как компонент личностно-ориентированной парадигмы образования // Народное образование. 2003. № 2. С. 58-64. Текст: непосредственный.

10. Черномырдина О. М. Использование интерактивных методов в процессе формирования общекультурной компетентности на уроках истории и обществознания // Муниципальное образование: инновации и эксперимент. 2011. № 2. URL: https://cyberleninka.ru/article/n/ispolzovanie-interaktivnyhmetodov-v-protsesse-formirovaniya-obschekulturnoy-kompetentnosti-na-urokah-istorii-i-obschestvoznaniya (дата обращения: 10.04.2021). Текст: электронный.

Статья поступила в редакцию 18.11.2021; одобрена после рещензирования 22.11.2021; принята к публикации 07.12.2021.

\section{FORMATION OF THE CADET BOARDING HIGH SCHOOLERS' GENERAL CULTURAL COMPETENCES ON HISTORY CLASSES}

Alexandra S. Shkilnyuk

Master's degree student,

Banzarov Buryat State University

25 Pushkin St., Ulan-Ude, 670000 Russia

alexsandra.shkilniuk@gmail.com

This article is devoted to the main task of Russian education, the provision of the state with highly cultured personalities who are able not only to possess theoretical knowledge, but also to be able to apply this knowledge in various activities. The article deals with the peculiarities of the formation of general cultural competencies on history lessons for senior students from the point of view of socio-cultural aspects. The author defines competence in general and socio-cultural competence in particular. This article examines the European and domestic classifications of key competencies. The author also indicates the directions of the formation of general cultural competencies on history lessons, at the same time, she offers possible options for working with senior students in class and extracurricular lessons in the discipline of history, aimed at the formation of general cultural competencies.

Keywords: general cultural competences, high school students, history lesson, socio-cultural aspect, intersubject connections, events.

The article was submitted 18.11.2021; approved after reviewing 22.11.2021; accepted for publication 07.12.2021. 